\title{
HOCAM SUUT KEMAL YETKIN
}

\section{Dr. Enise KANTEMIR (*)}

Estetik ve Sanat Tarihi alanında ülkemiz sınırlarını aşarak evrensel bir değere sahip olan Suut Kemal Yetkin'i 18 Nisan 19,80 günü sonsuza dek kaybettik. Ve asla yeri doldurulamayacak olan hocamızı güneşli bir bahar günü sonsuzluk alemine yolcu ettik.

Suut Kemal Yetkin, mutlu bir yaşam boyunca, çağdaş uygar. lık düzeyinin koşullarına uygun bir tutum ve davranışla sürekli olarak kendini yenilemiş bir yazar, eleştirmen, estetikçi, denemeci, sanat tarihçisi, düşünür, yönetici, akademisyendi. Ama bana göre, «O» hepsinin ötesinde gerçek Atatürkçü bir eğitimciydi.

1965 yllında, Ankara Üniversitesi bünyesi içinde öğretime açılan Eğitim Fakültesi'nin kurucularından biri olan Suut Kemal Yetkin; bu fakültenin Güzel Sanatlar Eğitimi Kürsüsü başkanı olarak, yaş sınırı nedeniyle emekli olduğu 1973 yłllına değin bu görevini büyük bir enerjiyle sürdürmüştür.

Suut Kemal Yetkin adıni, Lise son sinff edebiyat şubesinde iken Felsefe grubu içinde okutulan bana pek çekici gelen Estetik dersleri nedeniyle duymuş ve yazarmı da Estetik kitaibiyla tanımıştım. Bu ince kitap, o yllar bana yepyeni bir sanat dünyasının kapılarını aralamıştı. ... Ne zaman Suut Kemal'in yazdığı bir kitap çlksa hemen alır okurdum. 1945- 46 yllları Üniversite öğrencisiyken yazarın «1942» yllında yaymlanmış olan «Estetik Dersleri» kitabindan yararlanarak «Estetik Üzerine» adlı bir konferans vermiştim. «Eminönü Halkevinde» özellikle, «güzel», «iyi», «hoş», "yüce», "yararl1», «sempatik», gibi estetik değerleri şiirlerden örnekler seçerek somutlaşturmak istemiştim. Anısı, içimde hâlâ tazeliğini taşır. Ne heyacanlı ve ne güzel bir gecey-

* A.Ư. Eğitim Fakültesi Güzel Sanatlar Eğitimi Kürsüsü. 
di o gєce!.. Büyülk bị topluluk karşısında, okumadan konuşmak için aylarca bu konferansa hazırlanmıştım.

Aradan ylllar geçti, baş döndürücü bir süratle: Doğu Anadolu, Orta Anadolu da öğretmenlik yıllarım. Sonra Ankara Atatürk Lisesi, Ankara Koleji ögretmenlik ylllarm....

1967 - 1968 de Eğ̣̊tim Fàkültesi Güzel Sanatlar Eğitimi Kürsüsü öğretim görevliliği. Evet, bu kürsüye öğretim görevlisi olarak girmiştim ve Suut Kemal Yetkin, kem kürsü başkanım hem hocam ve hem de kısa zamanda çck sevip saydığımız onur verici aile dostumuz olmuştu: Ailece görüşürdük. Eşiyle birlikte bize geldikleri günler, eşim ve ben ne kadar mutlu olurduk. Hociam olmuştu. Çünkü önce mastır ve sonra da doktora programinı tamamlamışım. Suut Kemal'den esțetik doktrinler, barok sanat, ve edebiyat akımları denslerini aldık. Kürsüdeki arkadaşlarım Inci San. Cahit Kavcar ve Lisans ögrrencileri 1967'den 1973 Temmuz'una dek onunla biraradia çalışmış, onun sade fakat etkili konuşma, eleştiri ve sohbetlerinden yararlanmış, tartışmalarına katılmış gĞçekten mutlu kişileriz.

Kürsümüz O'nun kişiliğiyle güçlendi. $O$, güçlü kişiliğininin baskı ve eziciliğini kullanmadan sorunlarm üstesinden gelirdi. Bizimle arkadaşça, dostça konuşurdu. Asla öğüt vermez, fakàt uyarıcı olurdu. Çünkü «O» hoşgörülü ve alçak gönüllüydü.

Lisans dersleri ve özellikle kürsümüzdeki yüksek lisans ve doktoria dercleri son derece doyurucu ve zevkli geçerdi. Bizimle olan toplantıları ise canlı bir yaşam kürsüsüydü. Sürekli tartışmaya, eleştiriye açıktı.

Özgür düşünceye saygilı olan hocamızın sanatın eğitimdeki yerini ve önemini çok iyi vurgulayan yazıları çağdaş fikir ve düşüncelerini taşımaktadır.

Suut Kemal Yetkin'e göre : "Gerçekçi bir eğitim ilim ve sanatın ayrilmaz işbirliğine dayanmaktadır. Bu bakımdan insanda köklü bir ihtiyaca cevap veren sanatm, kişiliği eğiten en önemli etkenlerden biri olduğunu akıldan çlkarmamak gerekir. Sanat eğitiminin amacl, sanat için 'eğitim değil, sanatla eğitimdir. Böylø olunca yapılacak ilk iş, küçük yaşlardian itibaren insanı sanat eserleriyle karşı karşıya getirmek, uyuklama halindeki estetik 
duygusunu geliştirmektir. Bu ilk eğitim denemelerinden sonradriki öğrenci, sanat eserinin kendisiyle başbaşa kalabilir. ......... Mesele, insanda doğal olan sanat duygusunu geliştirerek kişiliğini bütünlemek için, onu sanat eserini görmeye ve tatmağa hazirlamaktir.»

Yeni yayımları sürekli izleyen ve «psikanaliz beni çók ilgilendirir.» diyen Suut Kemal Yetkin, bu konuda pek çok incelemeler bulunduğunu ve hatta 1934 de yayımlanan «Sanat ve Psikana.liz" adil makalesinde fikri sabitten sanat yoluyla nașl kurtulunacağını da belirtmişti.

Suut Kemal Yetkin : "Genel olarak eğitimin amaci, çocuğun psikolojik tipini meydana çlkarmak ve her tipe tabii çizgisi içinde gelişme, kendi biçimini bulma imkanı vermektir. Eğitim konusunda özgürlüğün gerçek anlamı budur. Bu sebepten dolayıdır kj, çocukların eğitiminde sanatın paha biçilmez bir önemi vardır.» demişti. Çünkü Yetkin, çocuğun kişiliğini bulana dek sanat disipliniyle geliştirilebileceği görüşündeydi. Yetkin'in çok önemli bulduğu, ve bu gün derinlikler psikolojisinin ortaya clkardığı bir gerçek de : «İnsan denilen yaratığın yalnız bilinçten ibaret olmadığı; bilincin, kat kat derinleşerek gittikçe karanlnğa gömülen altbilince oturmuş bulunduğu» gerçeğiydi. «O», bu gerçeği şöyle anlatmaktadır : "Bu karanlık bölge, çocukluğun ilk ylllairindon başlayan, boşalma imkanı bulmazsa adeta mayalaşarak tehlikelileşen türlü komplekslerin yaşadığı bölgedir. Çocuk oynayarak, insen rüya görerek sanatçı yaratarak bu komplekslerin zararından kurtulur. Burada, eğitim bakımından bizim için önemli olan, sanatçının kendi komplekslerini sembollerle yansitan eserlerinde, seyredenin de kendi komplekslerini bularak onlardan kurtulmasidır. Allnan sanat zevkinde bu kurtuluşun payı büyük olsa gerektir. Çünkü komplekslerin zararlıdan zararsıza getirilmesi, toplumca üstün hedeflere yöneltilmesi, kişi ve toplum yönünden önemi çok büyük olan psikolojik bir mekanizmadir.»

Zamanın çok iyi değerlendirilmesi gereğini öğütleyen Suut Kemạl Yetkin şu görüşteydi : "Yarın'ı yüklenecek olan çocuklarmulz, eksiksiz yetistirmek istiyorsak, rasyonel ve objektif düşüncenin gelişimini; duygunluğun, hayal gücünün ve kişisel dünyanın gelişimi ile dengelemek; ilimle sanatin temelinde ya- 
ratıcılık yattığına göre her iki güçten de çocưkları ve gençleri yararlandirmak zorundayız.:

Dil alanında sürekli kendini yenilemiş bir yazar olarak öğrencilerime «O» nu örnek gösterirdim. Türkçeyi yazllı ve sözlü olarak bütün incelikleriyle bir suyun berrak akışı kadar akıcı, duru, sade fakat etkili bir biçimde kullanır, yerli yerinde sözcüklerden örülü, sağlam bir mantığın disiplini içinde sınırlı ve etkili bir konusmayla dikkatlerimizi uyanık ve tetik tutmasinı bilirdi. Ağır ağı̀r sindirici bir tonla konuşur, gerekli vurgulamalları çok başarılı bir biçimde yapar, vücudun adali tonu demek olan, kapalı hareketleri çok iyi değerlendirir, açlk hareketlerden ise hafifçe ellerini kullanır, sözcüklerin anlamı ile hafif el harekketleri arasında çok iyi uyum sağlardı.

Suut Kemal Yetkin çok yönlü bir kişiydi. Fransız Dili v'e Edebiyatını ülkemizde en iyi bilenlerdendi. Fransızcayı șir gibi konuşurdu. Ve güzel bir diksiyonu vardı. Çoğu kez Türk edebiyatı yazarları ile Franșı edebiyatı yazarlarını karşılaştırır etki ve tepkileri örnekleriyle gözler önüne sererdi.

İyi bir deneme yazarıyd. Ülkemizde deneme türünün ilk ve en başarılı yapitlarını Nurullah Ataç'la "O" vermişti.

Ínceleyici araştırıcı bir yazardı. Bir gün kendisine : «Hocam ksonu seçerken metinlerinizi yazmadan önce nasıl bir hazırlığa girişir, yazarken hangi aşamalardan geçirirsiniz?» diye sorduğumda aymintılı bir biçimde şu yanıtı almıştım : «Bir yazıya başlamadan önce konuyu sinırlandirırım. Konuyla ilgili o yazıyı kafamda canlandırırım. Her yerde onu düşünürüm. Genellikle ben kkonuyu değil, konu beni seçer. Otururken, okurken, dolaşırken hep onu düşünürüm. Uzun bir düşünme döneminden sonra araşturma faslı başlar. Araştırma için çeşitli, kaynaklara baş vurucrum; hepsini büyükk bir titizlikle incelerim notlar alırım. Yerli ve yabancı karynaklardan aldiğım notlar fikir ve düşüncelerime dayanak olacak özelliktedir. Önce zihnimde bir plan taslağı yapar sonra bunu yaziya dökerim. Bu plana göre fikirlerimi tespit ederim; sonna bunları gelistiririm. Tekrar teknar okuyarak gereksiz olanlarmı atarım, Bu metni bir süre bir köşeye bırakır, unuturum; sonra yeniden taze bir yazıyla karşılaşmışcasına onu okurum. Uzunluk ve kısalık hakkında önceden kesin kararlı de- 
ğilim, ama çok uzun yazılardan genellikle nefret ederim. Yazmada olduğu gibi okumada da benim için bu böyledir, mizacım bu olduğundan böyle yazar, okurum. Bittiğini anladığım, artık üzerinde düşünmek ve duymak istemediğim an, metin bitmiş saysilur.

Bir sirrm daha var: Bir kitap yazmak isteyince onu ders olarak okuturum. Kitaplar için baskı gerekeceğinden, daha detrinlemesine ve daha yoğun bir çalş̧maya koyulurum. Gerek bilimsel metin gerek bilimsel eser hazrlamada kısa ya da uzun àynı aşamalardan geçerim.

Kitap hazırlama daha uzun bir süre gerektireceğinden günlük ve haftalık yaşamımı ona göre planlarım. Geceleri saat ikiye kadar, çalışırım. En verimli yazma saatlerim gecelerdir.»

Türk sanatını evrensel kamuoyunda tanitmak için verdiği uğraş saygıyla anılmaya değer. Ankara Üniversitesi Rektörlüğü sırasında, ilk kez uluslararası düzeyde, «Türk Sanâtları Kongresi» ni 1959 yılında düzenleyen «O» dur.

tyi bir eğitmen, hoca, güçlü bir sanatçı ve düşün adamı, başarılı bir yönetmen olan Suut Kemal Yetkin evine, eşine bağlı mutlu bir kişiydi. Ancak eşinin uzun süren hastalığı onu içten iyıkmıştı. Ölümünden kısa bir süre önce arkadaşlarım Dr. İnci San, Doç. Dr. Cahit Kavcar'la ziyaretine gitmiştik. Bizi, o her zamanki tebessümüyle karşlamıştı. Eş̧ini görmek istediğimde bama : «hayalinde o eski güzelliğiyle kalsa daha iyi olmazmı »de(mişti. Kallbinden rahatsız olduğunu söylemişti ama eskisi gibi sevecen ve içtenlikle doluydu. Anılarını yazıyordu, bize gösterdi, lisenin son yılarına kadar olan bölümü bitmişti. Bunları anlatırken heyecan doluydu. Ne yazlk anllarinı bitiremedi, keşke bitirebilseydi, anı edebiyatımız zengin bir yapit kazanacalktı : ...

Eserlerinin pek çoğunu imzalryarak bize armağan etmişti. Onları, ve yıl başı kartlarını değerli anı belgeleri olarak hep sakhıracağım.

Söz gücünü kaybetti fakat gene de söylemek istiyorum. Hocam, sizi sohbetlerinizi pek çok arıyor ve asla geri gelmeyecek o günlere özlem duyuyoruz.

Nur içinide yat. 


\section{SUUT KEMAL YETKIN'IN YAŞAM ÖYKÜSÜ}

1903 yılında Urfa'da doğan Suut Kemal Yetkin, Galatasaray Lisesinde orta öğrenimini; Paris'te Sorbonne'da ve Rennes Üniver'sitesi Edebiyat Fakültesinde yüksek öğrenimini tamamladı.

Yurda döndü, önce Gazi Eğitim Enstitüsü sonra Edirne Lisesi felsefe ögretmenliği yaptı. Bir ara müdür olarak aynı lisede yöneticilik görevini de üstlendi. Daha sonra İstaņ̧ul Üniviversitessi Edebiyat Fakültesinde doçent oldu «estetik ve sanat tarihi» derslerini okuttu (19,33).

1936 - 1939 ylllarında Dil ve Tarih Coğrafya Fakültesinde estetik ve sanat tarihi doçenti olarak görev yaptı. Bir süre Milli Ėğitim Bakanlığı .Güzel sanatlar Genel Müdürlüğünde bulundu.

1942 'de profesör clan Yetkin. 1942 - 50 yılları arasında iki dönєm: Urfa milletvekili olarak yaşamını sürdürdü.

1950 den sonra "O" nu gene üniversitede öğretim üyeliğine dönmüş olarak görüyoruz. Ankara Üniversitesi İlahiyat Fakültesinde iki kez Dekanlık görevlerini yürüttü. 1958'de Ord. Profesörüüğ̈üe yülsselen Yethin, 1959 - 63 ylllarmda Ankara Üniversitesi Rektörlüğü görevinde bulundu. Bu yıllarda kurulan Ankara Üniversitesi Basımevi «O» nun eseridir. Davetli olarak gittiği New York Columbia. Unniversitesinde konuk profesör olarak bir yll kadar Türk Sanatı dersleri verdi (1963-1964).

Suut Kemal Yetkin 1965 yılında Ankara Üniversitesi Eğitim Fakültesi kuruculari arasında yer aldı. Kuruluşunda büyük emeği gersen Suut Kemal Yetkin, bu fakültenin Güzel Sanatlar Eğitimi Kürsüsü Başkanı oldu. Kısa bir süre sonra da Hacettepe Ïniversitesi Sanat Tarihi Bölümünü kurmak üzere davet edildi ve bunda da, basarll oldu. Hem Hacettepe Üniversitesi 'Sanat Tarihi Bölümü Baskanlığ'ı hem de öğretim üyesi olarak her iki fakültede 1973 yılında yass smirı nedeniyle emekli olana dek görevlerini yürüttü.

Emekli olduktan sonra da evinde yazarliğını sürdüren Yetkin, 1974'te İslam Ülkelerinde Sanat, 1976'da Büyük Tedirginler, 1977'de Barok Sanat, 1978'de Edebiyat Üzerine Denemeler, 1979 da Estetik ve Ana Sorunlari adlı eserlerini yayımladi. En son 
lise son sınıf öğrenim yıllarına kadar geldiği anularını yazarken, 1980 ỵ̣lının 18 Nisan günü Ankara'da hayata veda etti.

Eserleri : 1923 d'e Şi'r-i Leyal adıyla bir şiir kitabı yaymlayan Yetkin'in 1930 dan sonra Varlık (1933), Insan (1938-43), Ülkü (1941 - 44), Sanat ve Edebiyat Gaizetesi (1947), Türk Dili (1951), Kültürr Dünyası (1954 - 55,) dergilerinde felsefe sanat ve edebiyaItın türlü konuları üzerinde yazıları çıłmıştır.

Suut Kemal Yetkin 1940'dan sonra deneme türüne ağırlık vermiş ve bu türün en başarılı örneklerini sunmuştur. Deneme türü yazılarinı içeren kitapları: Edebiyat Konu'şmaları (1944), Edebiyat Üzerine (1952), Günlerin Götürrdüğü (1958), Düşün Payı (1960), Yokuşa Doğru (1963), Şiir Üzerine Düşünceler (1969), Denemeler (1972), Edebiyat Üzerine Denemeler (1978) adlarmı ttaşır.

Diğer eserleri şunlardnr : İslam Mimarisi (1954) L'Architecture Turque en Turquis (1962), Edebiyatta Akımlar (1967), Büyük Ressamlar (1967), Baudlaire ve Kötülülk Çiçekleri (1967), Türk Mimarisi (1970), L'Ancienne Peinture Turque (1970), Estetik Doktrinler (1972), İslam Ülkelerinde Sanat (1974), Büyük Tedirginler (1976); Barok Sanat (1972), Estetik ve Ana Sorunları (1979).

Bunların dişında Suut Kemal Yetkin'in Milli Eğitim Bakanlığı yayınlarında çıkmış çevirileri, yerli ve yabancı dergilerde yatyımlanmiş inceleme, araştırma ve bilimsel yazıları vardır. 